\title{
Effect of Roller Path on the Formability of Drawing Spinning
}

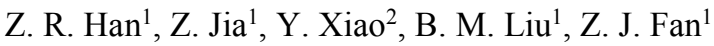 \\ ${ }^{1}$ Key Lab of Fundamental Science for National Defense of Aeronautical Digital Manufacturing Process, Shenyang Aero- \\ space University, Shenyang, 110136, China \\ ${ }^{2}$ School of Mechanical Engineering, Northwestern Polytechnical University, Xi'an, 710072, China
}

Drawing spinning is widely used for the manufacture of cylinder parts from disk blank. And the roller path can affect its formability strongly. But how does the effect mechanism work is rarely revealed. The plastic of the metal is one key factor for the failure of spinning such as fracture and wrinkling. In order to reveal the relationship between the roller path and the formability, two working conditions with one-pass (Scheme I) and multi-pass (Scheme II) roller path are proposed. And the comparative analysis of their metal flow evolution is carried out by the finite element method. It is found that one-pass roller path isn't conducive to putting down the flange gradually. And this will bring larger deformation resistance to cause cylinder wall fracture and reduce the formability of drawing spinning.

Keywords: Multi-pass roller path, Drawing spinning, Formability, FEM

\section{Acknowledgements}

This work was financially supported by the Natural Science Foundation of Liaoning Province, China (No. 201602558), and authors wish to express their gratitude.

\section{References}

[1] XIA, Q., XIAO, G., LONG, H, CHENG, X., SHENG, X. (2014). A review of process advancement of novel metal spinning. In: International Journal of Machine Tools and Manufacture, Vol.85, pp.100-121.

[2] HUANG, L. YANG, H., ZHAN, M. (2008). 3D-FE modeling method of splitting spinning. In: Computational Materials Science, Vol.42, No.4, pp.643-652.

[3] AHMED, K. I., GADALA, M. S., EL-SEBAIE, M. G. (2015). Deep spinning of sheet metals. In: International Journal of Machine Tools and Manufacture, Vol.97, pp.72-85.

[4] BAI, Q., YANG, H., ZHAN, M. (2008). Finite element modeling of power spinning of thin-walled shell with hoop inner rib. In: Transactions of Nonferrous Metals Society of China, Vol.18, No.1, pp.6-13.

[5] ZHAN, M., YANG, H., GUO, J., WANG, X. X. (2015). Review on hot spinning for difficult-to-deform lightweight metals. In: Transactions of Nonferrous Metals Society of China, Vol.25, No.6, pp.1732-1743.

[6] RUSNAKOVA, S., CAPKA, A., FOJTL, L., ZALUDEK, M., RUSNAK, V. (2016). In: Manufacturing Technology, Vol. 16, No.4, pp. 799-804.

[7] ZENG, C., ZHANG, S., XIA, Q., XIE, H. (2014). Research on effect of roller-races and process parameters on multi-pass drawing spinning quality. In: Forging \& Stamping Technology, Vol.39, No.1, pp.58-63. (in Chinese)

[8] XIA, Q., SHIMA, S., KOTERA, H., YASUHUKU, D. (2005). A study of the one-path deep drawing spinning of cups. In: Journal of Materials Processing Technology, Vol.159, No.3, pp.397-400.

[9] LIN B, GU J, ZHOU S, JIAN-MIN, G., WANG, D. (2010). Research on multi-process drawing spinning of Q235 and 1060 plates. In: Forging \& Stamping Technology, Vol.35, No.4, pp.56-59. (in Chinese)

[10] LIN, B. (2011) Research on Process of Multi-pass Draw-spinning of Hyper-hemispherical Shell. In: Journal of Mechanical Engineering, Vol.47, No.6, pp.86-91. (in Chinese)

[11] TREGLER, M., KEJZLAR, P., PILVOUSEK, T., ANDRŠOVÁ, Z., VOLESKÝ, L. (2016). The study of deformation behaviour of DC06 deep drawing steel. In: Manufacturing Technology, Vol. 16, No.1, pp.284-289.

[12] XIA, Q. X., CHENG, X. Q., HU, Y., RUAN, F. (2006). Finite element simulation and experimental investigation on the forming forces of 3D non-axisymmetrical tubes spinning. In: International Journal of Mechanical Sciences, Vol.48, No.7, pp.726-735.

[13] XIA, Q. X., XIE, S. W., HUO, Y. L., RUAN, F. (2008). Numerical simulation and experimental research on the multi-pass neck-spinning of non-axisymmetric offset tube. In: Journal of materials processing technology, Vol.206, No.1, pp.500-508. 
[14] JIANG, S. Y., ZHENG, Y. F., REN, Z. Y., LI, C. F. (2009). Multi-pass spinning of thin-walled tubular part with longitudinal inner ribs. In: Transactions of Nonferrous Metals Society of China, Vol.19, No.1, pp.215-221.

[15] JIANG, S. Y., REN, Z. Y., LI, C. F. XUE, K. M. (2009). Role of ball size in backward ball spinning of thin-walled tubular part with longitudinal inner ribs. In: Journal of materials processing technology, Vol.209, No.4, pp.21672174.

[16] MIAO, W., LIU, D., SHAO, X. (2014). Effects of Forming Parameters on Deformation Uniformity of Thin-walled Parts during Multi-pass Spinning. In: Journal of Netshape Forming Engineering, Vol.6, No.2, pp.18-22. (in Chinese)

[17] LI, Y., WANG, J., LU, G., PAN, G. (2014). A numerical study of the effects of roller paths on dimensional precision in die-less spinning of sheet metal. In: Journal of Zhejiang University SCIENCE A, Vol.15, No.6, pp.432446.

[18] WATSON, M., LONG, H. (2014). Wrinkling Failure Mechanics in Metal Spinning. In: Procedia Engineering, Vol.81, pp.2391-2396.

[19] E, D. X. (2007). Forming technology and die. Beijing Institute of Technology Press, Beijing. (in Chinese)

Copyright (C) 2017. Published by Manufacturing Technology. All rights reserved. 